\title{
Radial Growth of three Paecilomyces Species Isolated from Two Ghanaian Maize Varieties Abeleehi and Obaatanpa on Five Different Media and the Effects of their Culture Filtrate on Seed Germination and Radicle Elongation of Abeleehi and Obaatanpa
}

\author{
Andrew A. Minamor ${ }^{1 *}$ and G.T. Odamtten ${ }^{2}$ \\ ${ }^{1}$ Department of Science Laboratory Technology, Accra Technical University, \\ P. O. Box GP 561, Accra- Ghana \\ ${ }^{2}$ Department of Plant and Environmental Biology, School of Biological Sciences, \\ University of Ghana, P. O. Box LG 55 Legon \\ *Corresponding author
}

\section{Keywords}

Abeleehi,

Obaatanpa,

Maize Meal Agar,

Paecilomyces,

Radicle length.

\section{Article Info}

Accepted:

26 October 2016

Available Online:

10 November 2016

\section{A B S T R A C T}

Three xerophilic fungal species, Paecilomyces carneus, $P$. puntoni, and P. varioti were for the first time isolated from two newly-developed Ghanaian maize varieties; Abeleehi and Obaatanpa. The fungal species were isolated under varying ambient humidity of 55-65\% in both grain varieties. The culture filtrate of the Paecilomyces species raised in Maize Meal broth prepared from either Abeleehi or Obaatanpa and Potato-Dextrose broth were tested on the germination capacity of grains of Abeleehi and Obaatanpa using the blotter test method. The physiological condition for optimal growth of the Paecilomyces species were tested on Czapek-Dox Agar, Maize Meal Agar (Abeleehi), Maize Meal Agar (Obaatanpa), Malt Extract Agar and Potato Dextrose Agar at $(18,30,35$, and 40$){ }^{\circ} \mathrm{C}$. Radial growth of the Paecilomyces species was influenced by media and temperature of incubation. The optimum growth of $P$. carneus on all agar media used was obtained at a $30^{\circ} \mathrm{C}$, a temperature of $40^{\circ} \mathrm{C}$ was clearly unsuitable for growth of $P$. carneus as the fungus remained static at this temperature after 2-4 days growth. The best radial growth of $P$. puntoni was obtained between $30-35^{\circ} \mathrm{C}$. Growth at $18^{\circ} \mathrm{C}$ initially lagged behind those kept at $30^{\circ} \mathrm{C}$ but approximated their growth rate after 6 days incubation period. There was no statistical difference $(\mathrm{P} \leq 0.05)$ between growth of $P$. puntoni in all the media tested. Temperature of $35^{\circ} \mathrm{C}$ and $40^{\circ} \mathrm{C}$ depressed radial growth of $P$. varioti in all media tested. The best temperature for growth of $P$. varioti was $30^{\circ} \mathrm{C}$. Temperature $18^{\circ} \mathrm{C}$ was almost as suitable as $30^{\circ} \mathrm{C}$ for P. varioti. Radial growth of $P$. varioti was slowest on Potato Dextrose agar as compared to the other media tested. Percentage germination of the maize grains was depressed by $10-75 \%$ by the undiluted, 2, 4, and 8 days old culture filtrate of the three Paecilomyces species. However, there were varietal differences in the response of the germinating maize grains to the active ingredient in the culture metabolites of the three Paecilomyces species. The inhibitory effect was gradually removed with increasing dilution. The same culture filtrate severely depressed length of emerging radicles of the two maize varieties by $40-90 \%$ at the highest concentration applied. The reduction in radicle length was severer on Abeleehi variety as compared to Obaatanpa. 


\section{Introduction}

Seeds of cereal grains and legumes harvested from the field harbour both field fungi - mycoflora contaminating seeds in the field before harvest- and storage fungithose fungi that become resident during post-harvest storage of seeds-. These categories of fungi have been known to shorten the shelf-life of stored seeds; reducing seed viability, nutrient content and imparting toxic metabolites into the seed among others. During the first half of the twentieth century, knowledge of seed-borne diseases of crops has greatly increased and there is hardly any cultivated crop where at least one seed-borne fungal pathogen is not known (Malone and Musket, 1964). The extent of their occurrence and some idea of the damage they cause have been compiled by (Neergaard, 1983).

The reasons for this increased interest in seed-borne disease is due not only to technological advances which have made more detailed investigational work possible but also the increased attempt by man to cultivate new species and varieties of crops more suited to his needs.

Man has to introduce new species and varieties into territories where they not indigenous, to grow the same crop over wide areas to facilitate its hauling and harvesting of the produce and to produce maximum yields by intensive crop husbandry. All these factors have contributed to the incidence and spread of seed-borne disease and the growing need for further investigation and control of seed-borne pathogens (Minamor, 1995).

The Crop Research Institute of the Council for Scientific and Industrial Research, (CSIR) of Ghana has through the Grain and Legumes Improvement Programme, developed high lysine content maize grains including Abeleehi, Obaatanpa, Okomasa, Dobidi, to mention but a few which are being sold to the local farmers. However, there is hardly any information on the mycoflora associated with these grains which have to be stored for prolonged periods as seeds grains for the next planting seasons.

In this study, three Paecilomyces species, namely; P. carneus, P.puntoni, P. varioti isolated from Abeleehi and Obaatanpa among other genera and species at varying Environmental Relative Humidity provided by glycerol and water mixture. at $28-31^{\circ} \mathrm{C}$ for 6 days. These xerophilic species were isolated for the first time on stored Ghanaian maize varieties.

These fungi could be of pathological importance if their metabolites affect the viability and germination capacity of grains of Abeleehi and Obaatanpa used as seed maize in the next planting season. There is hardly any information in the pertinent literature on the physiological condition for optimal growth of these species isolated in Ghana. Five different natural and synthetic mycological media-Czapek- Dox Agar, Maize Meal Agar (Abeleehi), Maize Meal Agar (Obaatanpa), Malt Extract Agar and Potato-Dextrose Agar- were tested for ability to support optimal growth of the Paecilomyces species at different temperatures $(18,30,35,40 \text {, and } 45)^{\circ} \mathrm{C}$.

\section{Materials and Methods}

\section{Materials}

The maize varieties used Abeleehi and Obaatanpa were purchased from Aglow Seed Company, Accra. The fungal species, Paecilomyces carneus, Paecilomyces pntoni and P.aecilomyces varioti used in these investigations were isolated from the Abeleehi and Obaatanpa maize varieties. 


\section{General Methods}

\section{Maize Sample kept under humidity chamber}

Maize sample of Abeleehi and Obaatanpa varieties were kept at 55, 65, 75, 85 and 95\% Equilibrium Relative humidity (ERH) provided by glycerol; water mixtures at temperature of $28-31^{\circ} \mathrm{C}$ for 36 days.

\section{Direct - Plating Method}

The maize grains were surface-sterilized by washing in Milton's reagent (1\% sodium hypochlorite $+16.5 \%$ sodium chloride) for 5 mins and then rinsed with three changes of sterile water. Sodium hypochlorite treatment was used with the aim of reducing or removing completely external saprophytes which compete with pathogens. Ten (10) surfaced-sterilized grains were placed on either Sabouraud Dextrose Agar (Oxoid CM 41), Dichloran Glycerol Agar, DG 18 (Oxoid CM 727) in Petri plates without further treatment. The plates containing Sabouraud's Agar and DG 18 were incubated until fungi grew. There were 25 replicates for each grain variety.

\section{Serial - Dilution Method}

A $10 \mathrm{~g}$ sample of the grains was weighed and transferred aseptically into $100 \mathrm{ml} \quad 0.1 \%$ Peptone in $250 \mathrm{ml}$, Erlenmeyer flasks and then shaken in Gallenkamp Orbital at 140rev./min for 30mins. From this stock suspension, serial dilution was employed up to 1: $10 \mathrm{v} / \mathrm{v}$ and spores raised either in Sabourauds Agar (Oxoid CM 41) or Oxytetracycline Glucose Yeast Extract Agar (Oxoid CM 545). The objective of using two media is to recover a wider range of fungal species from the incubated grains. The plates were incubated at $28-31^{\circ} \mathrm{C}$ until fungi grew (7-14) days.

\section{Maintenance of stock Cultures}

Stock cultures of, Paecilomyces carneus, P.varioti, and P. puntonii, were maintained on slopes of Potato Dextrose Agar, slants in MacCartney tubes and sub-cultured every two weeks.

\section{Preparation of Media}

\section{(i) Potato Dextrose Agar}

Two hundred grams $(200 \mathrm{~g})$ of Irish potato was peeled, weighed and cut into slices. The cut slices were boiled in $500 \mathrm{ml}$ of water to become soft, thereafter, strained through cheese cloth and the slurry made up to the 1 litre mark. Twenty grams $(20 \mathrm{~g})$ of glucose and fifteen grams (15g) of agar were weighed separately and added into the solution. After heating on hot-plate for a few minutes to homogenize, the medium was sterilized in an autoclave at $121^{\circ} \mathrm{C}$ for 20mins.

\section{(ii) Maize Meal Agar Prepared from either Abeleehi or Obaatanpa}

Similarly, 200g maize weighed and blended and $500 \mathrm{ml}$ distilled water added. This was heated for a few minutes. The suspension was filtered through Buchner funnel to obtain a near clear solution. Twenty grams $(20 \mathrm{~g})$ of glucose and fifteen grams $(15 \mathrm{~g})$ agar were added and made up to 1litre mark with sterile distilled water. The medium was sterilized in an autoclave at $121^{\circ} \mathrm{C}$ for 20mins.

\section{Method of Inoculation}

Two diameters at right angles to each other were drawn at the bottom of the Petri plates $(9 \mathrm{~cm})$ with grease pencil after the agar medium had set. Each plate was held in inverted position, the lid was removed and 
the plate inoculated at the intersection of the two diameters with conidia on $2 \mathrm{~mm}$ Agar disks at the tip of a flamed - sterilized inoculation pin. The lid was placed back and the plates incubated in the inverted position. This method of inoculation completely obviated the usually sprinkling of powdery spores of Penicillium and Aspergillus species on plate inoculated in the upright position. In the case of Paecilomyces and Fusarium species, the agar disks bearing the inoculation was placed directly at the centre of the plate. The plates were inoculated in triplicate for each species and were inoculated at $18^{\circ}, 30^{\circ}, 35^{\circ}$ and $40^{\circ} \mathrm{C}$ respectively.

\section{Seed Viability Test}

Maize seeds completely free from fungal attacks were used in the viability test. Fifty seeds each of Abeleehi and Obaatanpa varieties were cut longitudinally to expose the germ region and then placed in sterile Petri dishes containing Tetrazolium Chloride solution. There were five replicates for each maize variety. The plates were incubated in total darkness for at least three hours. Thereafter the number of seeds showing characteristic pinkish colour in the germ region were counted and the percentage viability calculated.

In vitro studies on the effect of Fungal Metabolites on Germination and Radicle Elongation

Liquid static culture filtrate of the local isolates of Paecilomyces carneus, $P$. puntoni, $P$. varioti were obtained by raising the listed fungi (aliquot of $1.2-1.8 \times 105$ spores $/ \mathrm{ml}$ per flask) in either $30 \mathrm{ml}$ of Potato Dextrose Broth (PDB), Maize Meal Broth (MMB) prepared from both Abeleehi and Obaatanpa varieties. The mycelium was harvested after 2,4 and 8 days at $28-31^{\circ} \mathrm{C}$.
Vegetative growth was assessed by the convectional dry weight method and the cultural filtrates stored separately in $500 \mathrm{ml}$ Erlenmeyer flasks covered with black bags for immediate use.

The $\mathrm{pH}$ of the filtrate was taken using TOA pH meter HM - 60s (TOA Company Japan). The culture filtrate were used either undiluted or diluted $(1: 1,1: 2,1: 5$ and $1: 10 \mathrm{v} / \mathrm{v})$. Ten (10) grains of either Abeleehi or Obaatanpa varieties were placed on sterile filter paper in $9.0 \mathrm{~cm}$ Petri dishes moistened with $10 \mathrm{ml}$ distilled water (control) or with $10 \mathrm{ml}$ of culture filtrate of the listed fungi. There were 250 grains for each dilution level of culture filtrates and the period of growth, that is 2, 4, and 8 days of the respective fungi. Percentage germination was calculated after 5 days incubation at 28$31^{\circ} \mathrm{C}$ and the length of radicles noted. The length of the radicles (hypocotyl) are given as ratio (\%) to those of the control seedlings in distilled water (Kimura et al., 1992a).

\section{Results and Discussion}

Maize (Zea mays. L.) serves as the basis of the diet of millions of Ghanaians due to its versatile food uses and storage characteristics. In Ghana, maize is an important crop cultivated throughout the country with varying degrees of success depending on edaphic and climatic factors. Being a seasonal crop, especially in subSahara Africa, maize is stored as dry grains and forms an enormous reserve of food. The areas of maize cultivation in Ghana include the whole of Southern Ghana, Ashanti, Brong Ahafo, the three Northern Regions. Intensive commercial production of maize is however, found in the Somanya District of the Eastern Regions, the midland maize belt of Ashanti and Brong Ahafo Regions, the Ho - Kpandu District of the Volta Regions and Central Region. Unfortunately, maize is 
subject to a wide range of pathogens including viruses, bacteria, nematode, fungi both in storage and on the field. (Shurtleff, 1980) reported that of all these organisms, fungi are the main cause of the majority of diseases on maize.

The increased attempt by man to cultivate new varieties of crops more suited to his climate has necessitated breeding programmes that require crossing of local varieties with imported grain varieties which are not indigenous to Africa. The attendant problem is the production of new varieties whose versatility in terms of drought tolerance, yield and susceptibility to local indigenous diseases have not been thoroughly investigated prior to introduction of the crop to farmers. In this study, three Paecilomyces species namely; $P$. carneus, $P$. puntoni, and $P$. varioti were for the first time isolated from two recently developed Ghanaian maize varieties Abeleehi and Obaatanpa were investigated for their radial growth on five mycological media including Potato Dextrose agar, Czapek-Dox agar, Maize Meal agar prepared from either Abeleehi or Obaatanpa and Malt Extract agar. The culture filtrate of these xerophilic fungi raised on Maize Meal broth from either Abeleehi and Obaatanpa and Potato Dextrose broth were tested on the germination capacity and the effects of the culture filtrate on radicle development of the two maize varieties (Tables 1,2 \& 3).

Seed-borne fungi isolated from Ghanaian maize varieties Abeleehi and Obaatanpa for the first time in Ghana. Twelve (12) Aspergilus species predominated over the other species encountered followed by Penicillium nine (9) species. The species diversity was influenced by grain variety and the Environmental Relative Humidity $(\mathrm{ERH})$ at which the grains were incubated the xerophilic species of Paecilomyces ( $P$. carneus, $P$. puntoni, $P$. varioti) were isolated at $55-65 \%$ in both maize grain varieties (Minamor, A.A. 1995). Paecilomyces species are dominant in cereals stored in airtight condition by low ERH's. Paecilomyces varioti is a common contaminant in substrates from higher temperatures. The species is thermophilic growing even at $50{ }^{\circ} \mathrm{C}$ (Samson and Van Reenen Hoekstra, 1988). The local isolates of $P$. varioti grew best at $30-35^{\circ} \mathrm{C}$ (fig. 2 ) but could still thrive at $40^{\circ} \mathrm{c}$. The optimum growth for $P$. puntoni was between $35-40^{\circ} \mathrm{C}$ (fig.2). P. carneus grew at $30-35^{\circ} \mathrm{C}$ (fig, 1 ).

The striking feature of the local isolation of Paecilomyces species is that they continue to thrive even at $40^{\circ} \mathrm{C}$. The optimum temperature for growth of Paecilomyces species isolated elsewhere is close to what obtain for the Ghanaian species. For instance P.niveus (Stock and Samson) has an optimum temperature $30-35^{\circ} \mathrm{C}$, minimum about $10^{\circ} \mathrm{C}$, maximum $40^{\circ} \mathrm{C}$. P. fulvus, Stock and Samson, optimum $30-35^{\circ} \mathrm{C}$, minimum about $10^{\circ} \mathrm{c}$, maximum $45^{\circ} \mathrm{C}$ (Samson, 1974; Samson and Van ReenenHoekstra, 1988). In heated grains such as obtained in Stackburned grains, Paecilomyces species and other thermophilic species are likely to thrive and play a role in deterioration even under quiescent conditions in heated grains. Stackburn is the term used to describe maize grains stored in woven polypropylene sacks stacked in the warehouse which experience heated conditions of about $40^{\circ} \mathrm{C}$ up to 5 months and consequently become discoloured turning form white to varying shades of brown in the testa and germ regions. These grains are subsequently downgraded and disposed of cheaply - this constitute a loss to the farmer and the Warehousing agent, above all pose a threat to food security in sub-Sahara Africa. 
The inhibitory active ingredient in the metabolites of the three Paecilomyces species were formed even in two-day old culture filtrate on the various media used. The difference in shift of $\mathrm{pH}$ during vegetative growth of these fungal species in culture may reflect the varying chemical composition of the metabolites of the fungal species. These metabolites when used undiluted depressed seed germination of the Ghanaian maize variety Abeleehi and Obaatanpa by $10-80 \%$ and drastically reduced ( $\geq 45-85 \%$ ) length of the emerging radicles at the highest concentration applied. The reduction in length of radicle was severer on Abeleehi variety as compared to Obaatanpa where culture metabolites of P.carneus, P. puntoni, and P.varioti were applied. The inhibitory effect of the metabolites was however, gradually removed with dilution such that the radicle lengths of the germinating grains in the presence of $1: 10 \mathrm{v} / \mathrm{v}$ dilution of the filtrate nearly approximated that of the control (distilled water) in some instances.

Table.1 Culture filtrate of Paecilomycs puntoni growing in Potato Dextrose Broth used as germination medium for maize varieties - Abeleehi and Obaatanpa.

\begin{tabular}{|c|c|c|}
\hline $\begin{array}{l}\text { Dilution } \\
\text { Ratio }\end{array}$ & $\begin{array}{l}\text { Radicle Length AS \% of } \\
\text { Control }\end{array}$ & $\begin{array}{l}\text { Radicle Length as \% of } \\
\text { Control }\end{array}$ \\
\hline
\end{tabular}

2 - DAY OLD

\begin{tabular}{|lc|lc|}
\hline & (ABELEEHI) & (OBAATANPA) \\
UNDILUTED & 36 & UNDILUTED & 40 \\
$1: 1$ & 46 & $1: !$ & 56 \\
$1: 2$ & 53 & $1: 2$ & 67 \\
$1: 5$ & 91 & $1: 5$ & 80 \\
$1: 10$ & 97 & $1: 10$ & 100 \\
\hline
\end{tabular}

4 - DAY OLD

\begin{tabular}{|c|c|c|c|}
\hline UNDILUTED & 26 & UNDILUTED & 24 \\
\hline $1: !$ & 33 & $1: !$ & 24 \\
\hline $1: 2$ & 48 & $1: 2$ & 38 \\
\hline 1: 5 & 65 & 1: 5 & 73 \\
\hline $1: 10$ & 76 & $1: 10$ & 76 \\
\hline
\end{tabular}

\section{8 - DAY OLD}

\begin{tabular}{|c|c|c|c|}
\hline UNDILUTED & 40 & UNDILUTED & 54 \\
\hline $1: !$ & 58 & $1: !$ & 65 \\
\hline $1: 2$ & 78 & $1: 2$ & 81 \\
\hline 1: 5 & 85 & $1: 5$ & 84 \\
\hline $1: 10$ & 96 & $1: 10$ & 94 \\
\hline
\end{tabular}


Table. 2 Culture filtrate of Paecilomycs puntoni growing in Maize Meal Broth (Abeleehi) used as germination medium for maize varieties - Abeleehi and Obaatanpa

\begin{tabular}{|lc|lc|}
\hline $\begin{array}{l}\text { Dilution } \\
\text { Ratio }\end{array}$ & $\begin{array}{l}\text { Radicle Length AS \% of } \\
\text { Control }\end{array}$ & $\begin{array}{l}\text { Dilution } \\
\text { ratio }\end{array}$ & $\begin{array}{l}\text { Radicle Length as \% of } \\
\text { Control }\end{array}$ \\
\hline \multicolumn{4}{|c|}{ 2 - DAY OLD } \\
\hline UNDILUTED & (ABELEEHI) & UNDILUTED & 23 \\
$1: 1$ & 25 & $1: !$ & 30 \\
$1: 2$ & 30 & $1: 2$ & 34 \\
$1: 5$ & 39 & $1: 5$ & 40 \\
$1: 10$ & 61 & $1: 10$ & 61 \\
\hline
\end{tabular}

4 - DAY OLD

\begin{tabular}{|ll|ll|}
\hline & & & \\
UNDILUTED & 29 & UNDILUTED & 39 \\
$1: !$ & 35 & $1: !$ & 50 \\
$1: 2$ & 47 & $1: 2$ & 49 \\
$1: 5$ & 62 & $1: 5$ & 67 \\
$1: 10$ & 80 & $1: 10$ & 79 \\
\hline
\end{tabular}

8 - DAY OLD

\begin{tabular}{|c|c|c|c|}
\hline UNDILUTED & 40 & UNDILUTED & 48 \\
\hline $1: !$ & 48 & $1: !$ & 52 \\
\hline $1: 2$ & 66 & $1: 2$ & 62 \\
\hline 1: 5 & 69 & 1: 5 & 69 \\
\hline $1: 10$ & 92 & $1: 10$ & 74 \\
\hline
\end{tabular}


Table.3 Culture filtrate of Paecilomycs puntoni growing in Maize Meal Broth (Obaatanpa) used as germination medium for maize varieties - Abeleehi and Obaatanpa

\begin{tabular}{|lc|lc|}
\hline $\begin{array}{l}\text { Dilution } \\
\text { Ratio }\end{array}$ & $\begin{array}{l}\text { Radicle Length AS \% of } \\
\text { Control }\end{array}$ & $\begin{array}{l}\text { Dilution } \\
\text { ratio }\end{array}$ & $\begin{array}{l}\text { Radicle Length as \% of } \\
\text { Control }\end{array}$ \\
\hline \multicolumn{4}{|c|}{ 2 - DAY OLD } \\
\hline UNDILUTED & (ABELEEHI) & UNDILUTED & (OBAATANPA) \\
$1: 1$ & 25 & $1: !$ & 30 \\
$1: 2$ & 30 & $1: 2$ & 34 \\
$1: 5$ & 39 & $1: 5$ & 40 \\
$1: 10$ & 61 & $1: 10$ & 61 \\
\hline
\end{tabular}

4 - DAY OLD

\begin{tabular}{|c|c|c|c|}
\hline UNDILUTED & 23 & UNDILUTED & 21 \\
\hline $1: !$ & 29 & $1: !$ & 26 \\
\hline $1: 2$ & 45 & $1: 2$ & 54 \\
\hline 1: 5 & 50 & 1: 5 & 61 \\
\hline $1: 10$ & 85 & $1: 10$ & 83 \\
\hline
\end{tabular}

8 - DAY OLD

\begin{tabular}{|c|c|c|c|}
\hline UNDILUTED & 55 & UNDILUTED & 45 \\
\hline $1: !$ & 63 & $1: !$ & 63 \\
\hline $1: 2$ & 92 & $1: 2$ & 63 \\
\hline 1: 5 & 93 & 1: 5 & 83 \\
\hline $1: 10$ & 95 & $1: 10$ & 85 \\
\hline
\end{tabular}


Fig.1 Radial growth of Paecilomyces carneus on five different mycological media (Indicated).
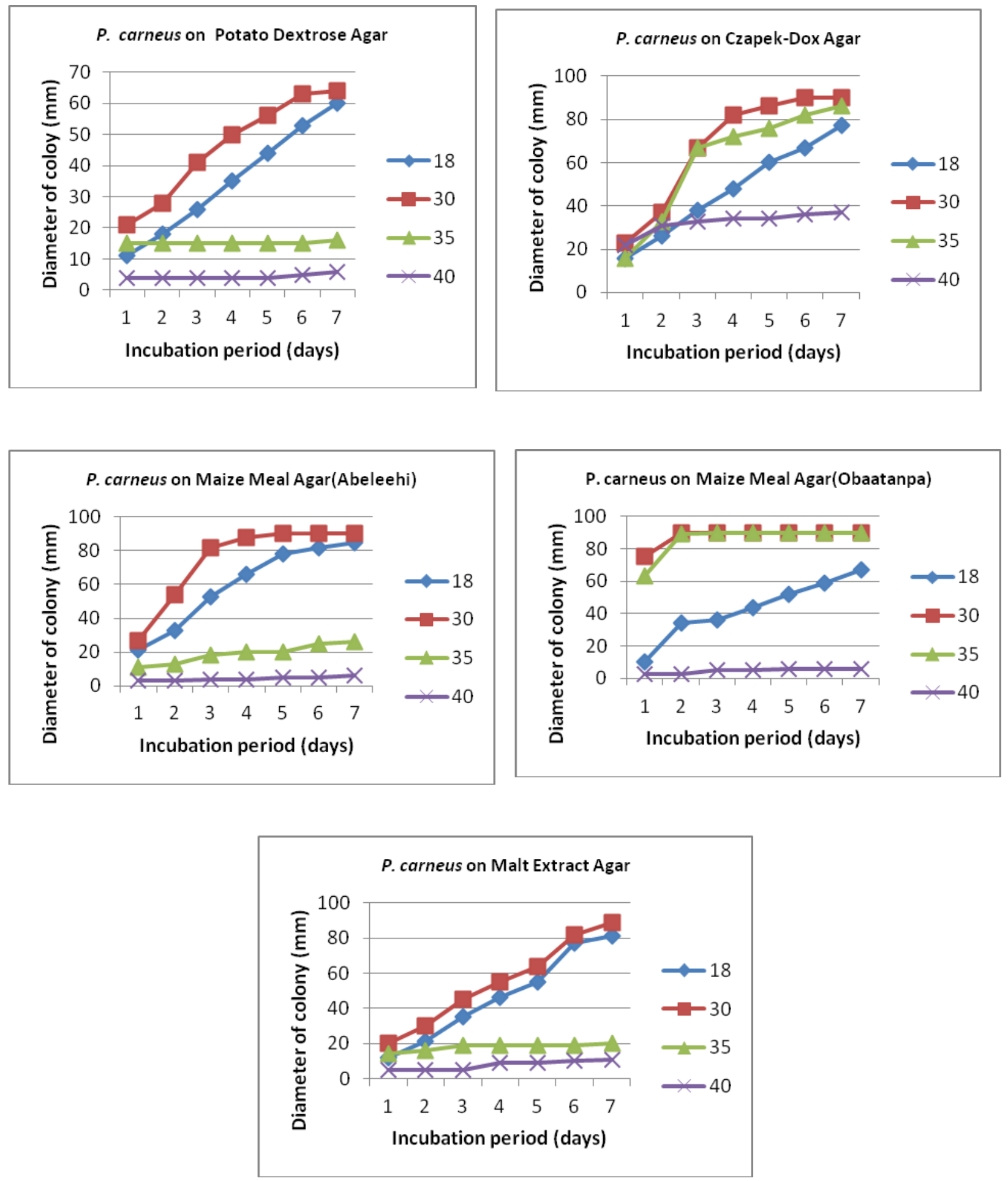
Fig.2 Radial growth of Paecilomyces puntoni on five different mycological media. (Indicated)
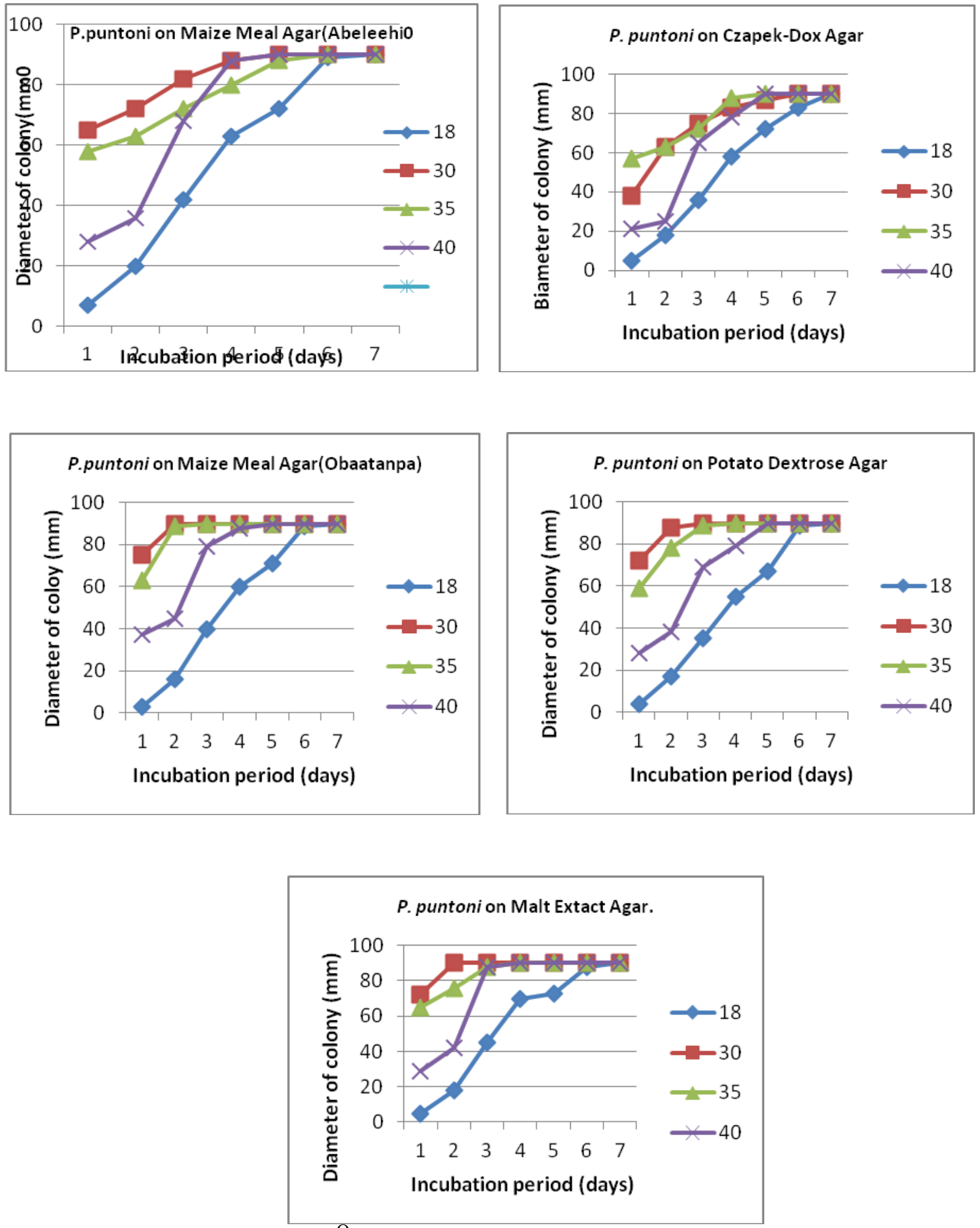

Note: The growth at $18^{\mathrm{O}} \mathrm{C}$ initially lagging behind the remaining temperatures. 
Fig.3 Radial growth of Paecilomyces varioti on five different mycological media (Indicated).
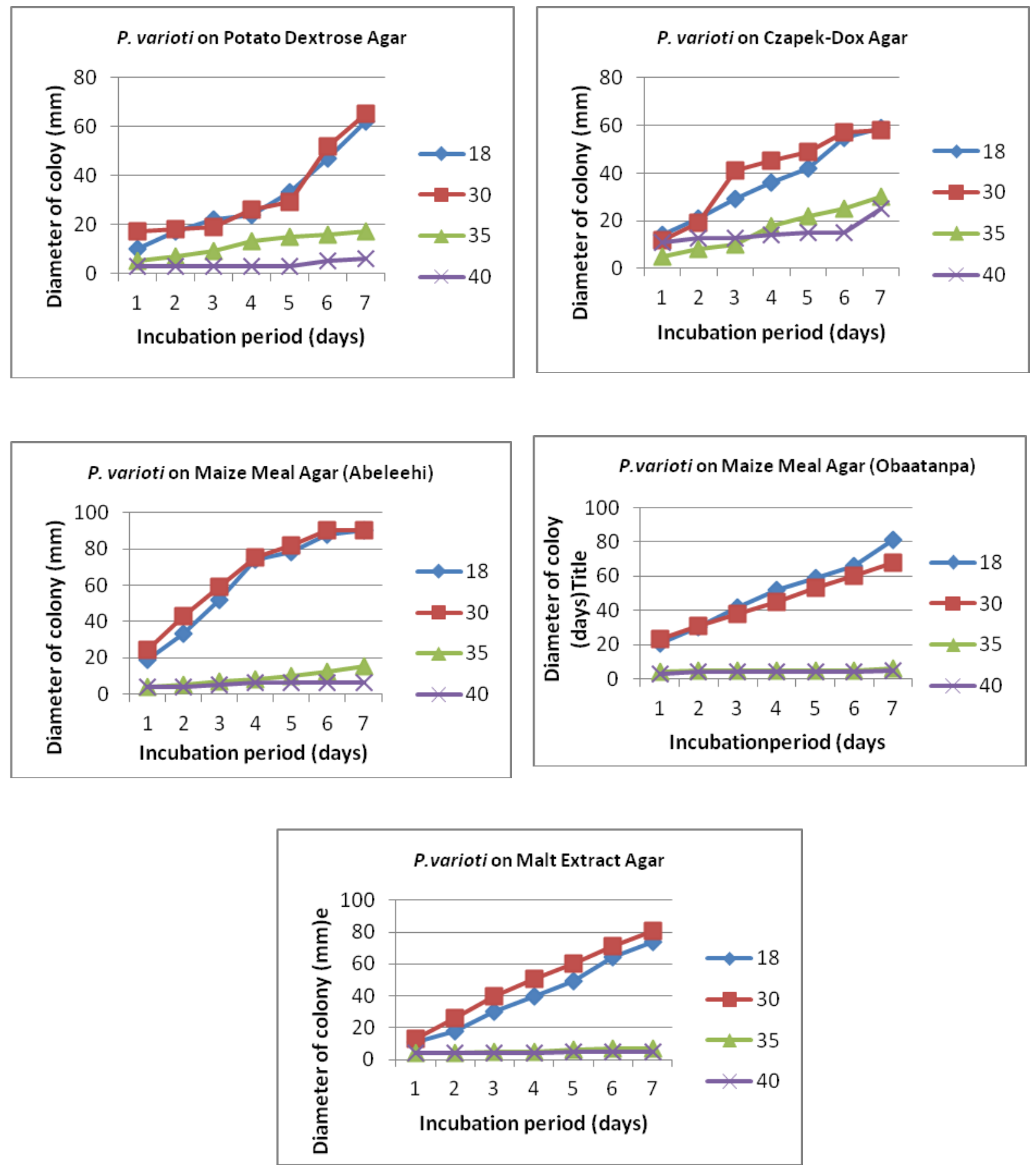

Note: The slow growth of fungus on PDA 
Fig.4 Influence of 4-day old culture filtrate of P.carneus on radicle length of germinating seeds of Abeleehi(left) and Obaatanpa (right). Top: Left (Control); Middle (1:10v/v); Right (1:5v/v) Bottom: Left $(1 ; 2 \mathrm{v} / \mathrm{v})$; Middle $(1: 1 \mathrm{v} / \mathrm{v}) ;$ Extreme right (undiluted)
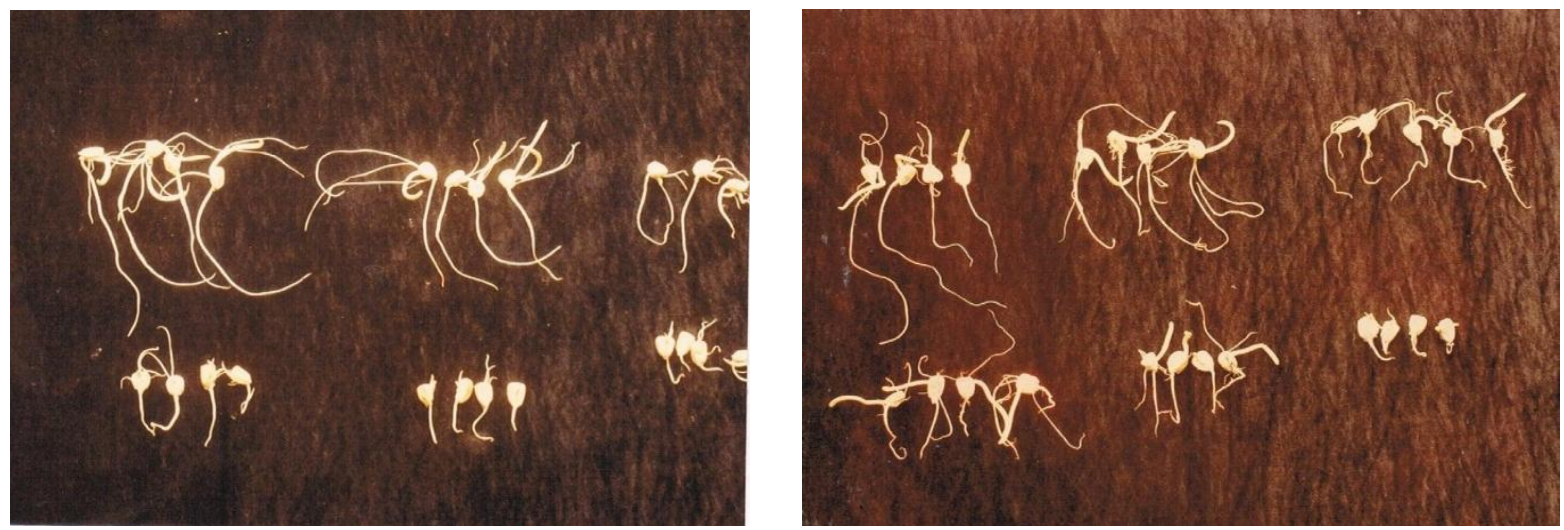

Fig.5 Influence of 4-day old culture filtrate of P.puntoni on radicle length of germinating seeds of Abeleehi(left) and Obaatanpa(right). Top: Left (Control); Middle (1:10v/v); Right (1:5v/v) Bottom: Left $(1 ; 2 \mathrm{v} / \mathrm{v}) ;$ Middle $(1: 1 \mathrm{v} / \mathrm{v})$; Extreme right (undiluted)
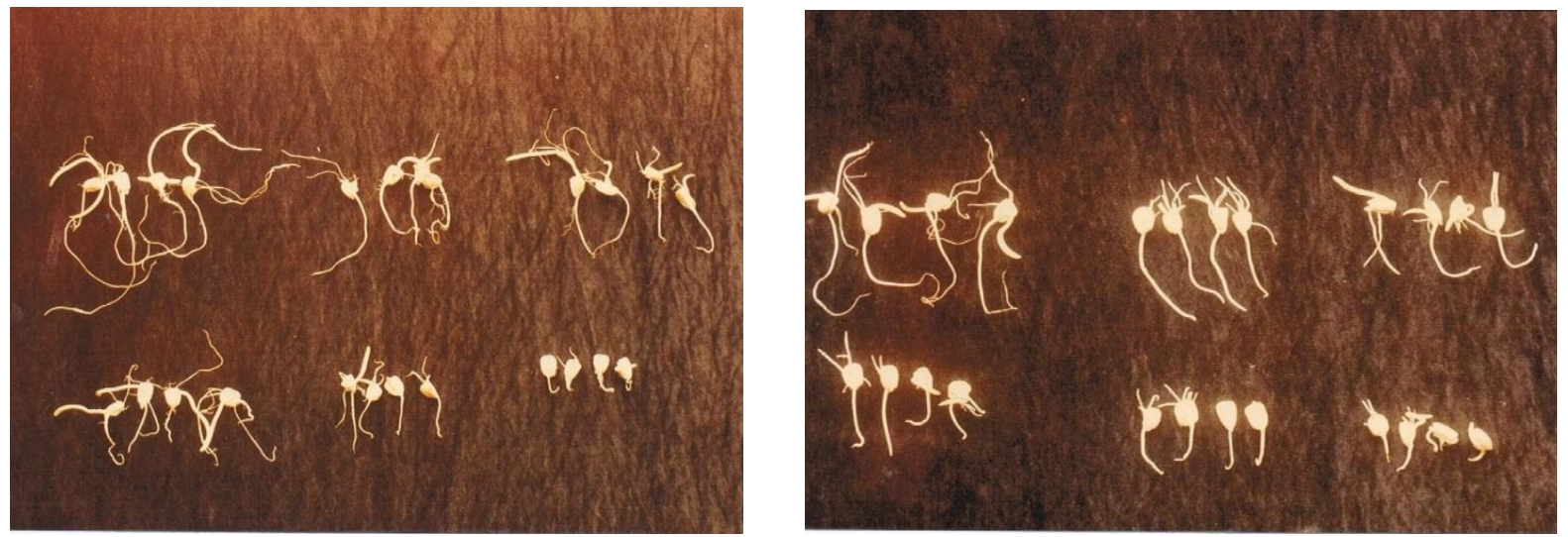

Fig.6 Influence of 4-day old culture filtrate of P.varioti on radicle length of germinating seeds of Abeleehi(left) and Obaatanpa(right). Top: Left (Control); Middle (1:10v/v); Right (1:5v/v) Bottom: Left (1;2v/v); Middle (1:1v/v); Extreme right (undiluted).
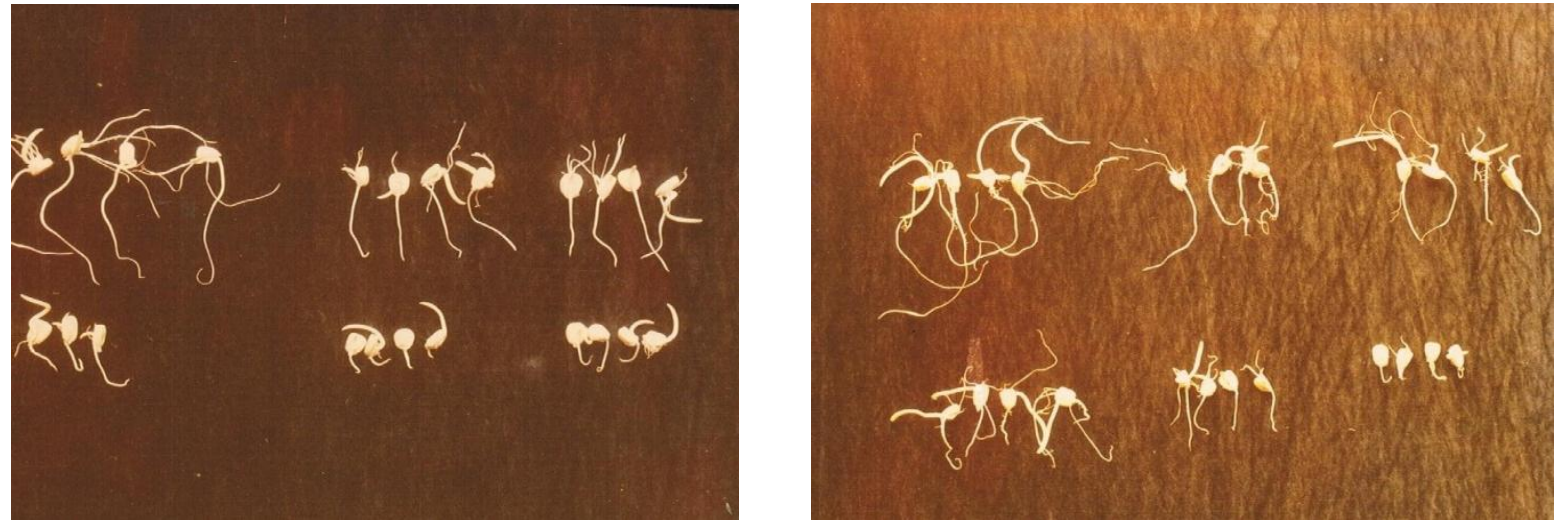
The maize varietal differences in response to germination and radicle development in the presence of the metabolite in vitro could be attributed to the intrinsic genotypic differences in the seeds and also the possible variation in the composition of the metabolites from the three Paecilomyces species.(Figs. 4, 5 \& 6). Paecilomyces varioti produces patulin, a mycotoxin (Frisvad, 1988) but the nature of the mycotoxins from P.carneus, P. puntoni have not been clearly elucidated to date.

In conclusion, the data in this paper indicates that radial growth of Paecilomyces species on agar was influenced by the media and temperature of incubation; each Paecilomyces species behaved differently. The optimum growth of $P$. carneus on all agar used was obtained at a $30^{\circ} \mathrm{C}$, a temperature of $40^{\circ} \mathrm{C}$ was clearly unsuitable for growth of $P$. carneus as the fungus remained static at this temperature after $2-4$ days growth.

The best radial growth of $P$. puntoni was obtained between $30-35^{\circ} \mathrm{C}$. Growth at $18^{\circ} \mathrm{C}$ initially lagged behind those kept at $30^{\circ} \mathrm{C}$ but appproximated their growth rate after 6 days incubation period. This was no statistical difference $(\mathrm{P} \leq 0.05)$ between growth of $P$. puntoni in all the media used. Temperature of $35^{\circ} \mathrm{C}$ and $40^{\circ} \mathrm{C}$ depressed radial growth of $P$. varioti in all media tested. The best temperature for growth of $P$. varioti was $30^{\circ} \mathrm{C}, 18^{\circ} \mathrm{C}$ was almost as suitable as $35^{\circ} \mathrm{C}$ for $P$. varioti. Radial growth of P. varioti was slowest on Potato Dextrose agar as compared to the other media tested. The three P. species produced their inhibitory metabolites in 2 days in the media used to culture the species. Percentage germination of maize grains was depressed by $10-75 \%$ by culture filtrates of the species. The same culture filtrate severely depressed length of the two maize varieties by $45-90 \%$ at the highest concentration applied. The reduction in length of radicle was severer on Abeleehi variety as compare to Obaatanpa. However, the inhibitory effect was gradually removed with dilution such that the radicle lengths of the germinating grains in the presence of 1: $10 \mathrm{v} / \mathrm{v}$ dilution of the filtrate nearly approximated that of the control in some instances.

\section{Acknowledgement}

The authors are grateful to the University of Ghana for laboratory facilities for this work at the Department of Plant and Environmental Biology. All the technicians at the department deserve our warmest gratitude for their various technical assistance. Finally, we thank Mr. Bonah a Senior Laboratory Technologist of the Department of Science Laboratory Technology, Accra Technical University for kindly arranging the graphs and the tables.

\section{References}

Frisvad, J.C. 1988. Fungal species and their specific production of mycotoxin. In: Samson, R.A., and Reenen-Hoekstra E.S. Chapter 4. Introduction to foodborne fungi, CBS. Institute of the Royal Netherlands Academy of Arts and Sciences Pp. 249-249.

Kimura, Y. Shiojima, K., Nakajima H., and Hamasaki, T. 1992b. Altechromes A and $\mathrm{B}$, new plant growth regulators produced by the fungus Alternaria sp. Bio. Sci. Biotech. Biochem., 56(10): 1664-1665.

Malone, J.P. and Muskett, A.E. 1964. Seedborne fungi. Description of 77 fungus species, Proc. Int. Test Ass., 29: 179384.

Minamor, A.A. 1995. Influence of the metabolites of three Paecilomyces 
species on the germination and seedling development of two Ghanaian maize varieties (Abeleehi and Obaatanpa). M. Phil. Thesis, Department of Plant and Environmental Biology, School of Biological Sciences, University of Ghana.

Neergaard, P. 1983. Seed Pathology Vol 1. The MacMillian Press Ltd. London and Basingstoke Company 283-297.

Samson, R.A. 1974. Paecilomyces and some allied Hyphomycetes Stud. Mycol., Baarn 6: 119pp. In; Introduction to food-borne fungi 3rd Edition CMS. Institute of the Royal Netherlands Academy of Arts and Sciences.

Samson, R.A., and Van Reenen-Hoekstra, E. 1988. Introduction to food-borne fungi 3rd Edition Centraalbureau Voor Schimmel Cultures Baar. Institute of the Royal Netherlands Academy of Arts and Sciences.

\section{How to cite this article:}

Andrew A. Minamor and G.T. Odamtten. 2016. Radial Growth of three Paecilomyces Species Isolated from Two Ghanaian Maize Varieties Abeleehi and Obaatanpa on Five Different Media and the Effects of their Culture Filtrate on Seed Germination and Radicle Elongation of Abeleehi and Obaatanpa. Int.J.Curr.Microbiol.App.Sci. 5(11): 604-617. doi: http://dx.doi.org/10.20546/ijcmas.2016.511.071 